\title{
Contemporary trends in the judicial practice of compensation for damage in commissioning environmental crimes
}

\author{
Aleksander Salyakhovich Blankov ${ }^{11}$, Olga Borisovna Vinogradova ${ }^{1}$, Rezo Tengizovich \\ Gaprindashvili², Yulia Rudolfovna Orlova ${ }^{1}$, and Svetlana Petrovna Portyankina ${ }^{3}$ \\ ${ }^{1}$ State University of Land Use Planning, Department of Criminal Law Disciplines, Moscow, Russia \\ ${ }^{2}$ State University of Land Use Planning, Department of Law, Moscow, Russia \\ ${ }^{3}$ State University of Land Use Planning, Department of Civil Law, Civil and Arbitration Procedure, \\ Moscow, Russia
}

\begin{abstract}
The prerequisites for the research were a comprehensive analysis of the state of environmental safety in the Russian Federation indicative of negative trends in this area including the compensation for harm caused as a result of committing environmental crimes. The article presents the results of the analysis of the criminal case files related to compensation for harm caused as a result of committing environmental crimes. The research authors noted such a feature of environmental crimes that when they are committed, the damage is caused to objects that have both environmental and economic value. Often, at the same time, environmental damage is caused to a certain extent by economic (property) damage (harm) which significantly complicates the resolution in practice of the issue related to compensation for harm caused as a result of committing environmental crimes. The core problem identified by the authors is that environmental harm from the point of view of its complex manifestation cannot be detected immediately, but after a rather long time; there are cases when it can be completely irreparable. The authors made an attempt to summarise the law enforcement practices of Russian courts related to compensation for harm caused as a result of committing environmental crimes, both at the stage of preliminary investigation and judicial proceedings, consider the types of harm to be compensated and the recovery procedure, identify problems arising during compensation for various types of harm. Based on the research results, measures aimed at improving the mechanism of legal regulation of compensation for harm caused as a result of violation of environmental safety rules were proposed; the need for legislative consolidation of the criteria for determining the amount of compensation for harm by the courts, as well as the need for specialisation of courts considering cases related to environmental offences.
\end{abstract}

Keywords: compensation for damage to the environment, environmental crimes, the amount and method of compensation, environmental restoration

\footnotetext{
${ }^{1}$ Corresponding author: as blankov1@mail.ru
} 


\section{Introduction}

In the contemporary context, the issues of studying the means of protecting the environment and guaranteeing the right of citizens to the favourable state of environment including those related to imposing on the person, who caused harm as a result of the commission of an environmental crime, the obligation to compensate for it, as well as the obligation to suspend, limit or terminate activities creating a risk of causing harm in the future are becoming rather relevant. The level of criminal encroachments on the environment and amount of environmental damage caused by them testifies to the scale of this negative social and legal phenomenon, and the need to intensify scientific research in that area including through the study of positive overseas experience. So, at the end of 2020 alone, 22,676 environmental crimes were registered in the Russian Federation (year-on-year - 22,230), an increase of about $2 \%$. Of the registered crimes, only less than half $-10,918$ were solved [1].

An analysis of the data of the Judicial Department showed that in 2019, Russian courts received 10,102 criminal cases initiated under Art. 246-262 of the Criminal Code of the Russian Federation (environmental crimes). Of these, $52.7 \%(5,332)$ were considered on the merits and sentences were passed in respect of them, $40.9 \%$ (4141) cases were terminated, in respect of $2 \%$ (205) cases were returned to the prosecutor to eliminate the shortcomings in accordance with Art. 237 of the Code of Criminal Procedure of the Russian Federation in connection with the refusal to accept or terminate a criminal case.

In total, 6,379 people were convicted on environmental crimes, 19 were acquitted. Of the terminated ones, 12 were terminated on rehabilitating grounds, 4,723 were terminated on other grounds. In respect of 1,387 , criminal cases were terminated, subject to the appointment of a court fine as preconditions for the release from criminal responsibility of the perpetrators. Compulsory measures of a medical nature were applied in respect of 48 people. An interesting fact is that in relation to 60 convicted persons, the court approached differentially and in accordance with Art. 15 of the Criminal Code of the Russian Federation changed the category of the crime to a less serious one (usually from a crime of medium gravity to a crime of small gravity) [2].

On 19 April 2017, adopted was the decree of the President of the Russian Federation No. 176 "Strategy of Environmental Safety of the Russian Federation up to 2025" which determined the preservation and restoration of the natural environment and guaranteed the environmental quality necessary for a favourable human life and sustainable development of the economy, elimination of the accumulated harm to the environment due to economic and other activities [3]. At the same time, the environmental safety analysis in the territory of the Russian Federation points to the fact that an increase in production volumes in the fuel and energy sector, oil and gas industry, provided that old process equipment is used, inevitably leads to an increase in the negative impact on the environment, disasters and, as a consequence, the commission of environmental offences and crimes. We fully agree with the opinion of the group of researchers Kodolova and Solntsev who in their work "Bringing to Liability for Causing Harm to the Environment in Russia and Foreign Countries: Ways to Improve Legislation" determined that "the existing system of bringing to liability for harm caused to the environment in our country cannot be called effective" [4].

\section{Results and discussion}

Our applied research allowed us to identify some features in the field of legal proceedings in cases relating to the commission of environmental crimes and offences. Despite a slight increase by $2 \%$ in the total number of administrative and criminal cases for 
environmental violations in 2020, the number of crimes directly related to the infliction of exclusively environmental harm as a result of the activities of enterprises and organisations (legal entities) is gradually decreasing. The state remains stable only due to such crimes as illegal hunting or illegal felling of forest plantations. The total amount of fines levied for environmental violations for the year amounted to 975 million roubles. This is more than a hundred times less than the annual penalties from car users [5]. According to the most optimistic estimates, the net profit of enterprises is two times lower than the amount of damage caused to the environment as a result of their operation [6].

According to the Judicial Department, there has been a decrease in the total number of people convicted for environmental crimes. So, if in 2015 almost 9,000 people were convicted, then in 2017 about 7,000, and in 2019 - 6,189 [7]. B. Morgunov, Director of the Institute of Ecology of the National Research University of the Higher School of Economics, is also confident that the number of punishments is not indicative of the real environmental situation. He believes that the degree of violation largely depends on the position of the representative of Rosprirodnadzor (Federal Service for Supervision of Natural Resources) [5].

So, on 5 February 2021, the Krasnoyarsk Territory Arbitration Court passed an unprecedented judgement in the Russian judicial practice in case No. A33-27273/2020 concerning the claim of Rosprirodnadzor against Norilsk-Taimyr Energy Company (NTEC) JSC for the recovery of 146.17 billion roubles as compensation for environmental damage caused as a result of tank depressurisation and fuel spills. As a result of the accident, more than 21,000 tons of oil products got into water bodies and soil. The Ministry of Natural Resources initially intended to recover a fine from Norilsk Nickel without a trial but later, a lawsuit was filed, since Norilsk Nickel did not agree with the methodology for assessing the harm caused to the ecological system. In their opinion, the damage amounted to 21.4 billion roubles [8].

The Yenisei interregional administration of Norilsk Nickel did not agree with the court's judgement, it insisted that the calculations used an incorrect exposure duration coefficient, and that the weight of oil products, that got into the water, was incorrectly determined. At the same time, the Norilsk Nickel representatives substantiated their position by the fact that the exposure duration coefficient shows how long oil products had an impact on water bodies with a lack of any oil spill response measures, and Rosprirodnadzor determined its value equal to 5 . This coefficient is used when measures to eliminate damage are not for a long time [9]. In addition, according to experts, such a maximum exposure duration coefficient can be used in the case of soluble petroleum products. The subject of this crime, diesel fuel, does not apply to them.

The second controversial argument of the opponents was the assertion that Rosprirodnadzor estimated the weight of oil products that got into the water before the end of the collection work. However, during the proceedings, the court refused to satisfy the requests of Norilsk-Taimyr Energy Company representatives to appoint a new expert examination in respect of restoring the natural environment in kind. Failing to reach an agreement on the amount of damage, the environmental department filed a lawsuit in the amount of 147.7 billion roubles, which was partially satisfied). Of 146.17 billion roubles, 145.49 billion roubles were sent to the federal budget, and the recipient of the remainder was the budget of the affected constituent entity of the Russian Federation, the city of Norilsk. At the same time, criminal cases against the perpetrators under four articles, such as "spoilage of land", "violation of environmental protection rules during the production of work", "water pollution" and "negligence" were initiated. 
However, the recipient of the funds has not yet been identified. It is planned to adjust the reimbursement mechanism so that the payment goes not to the municipal budget but the federal centre. This situation became possible due to the size of the unprecedented amount of compensation - 147 billion roubles - this is the size of eight annual budgets of the city. According to the Ministry of Finance, by the end of 2020, Norilsk can expect revenues of 18 billion roubles; and it was considered absurd to appropriate additional funds in the amount of 148 billion roubles there [10].

Undoubtedly, the analysis of one cited decision (especially one that has not yet entered into legal force) cannot be a reflection of the entire law enforcement practice of Russian courts on compensation for damage caused as a result of committing environmental crimes. Oddly enough, it accumulates in itself all the key problems arising in the course of making decisions by courts in such cases, how and in what form should be compensated for damage caused as a result of violation of environmental legislation; what taxes should be calculated, how the calculation of harm to the environment should be allowed if there are no taxes and methods; how and at what point the actual costs incurred by the guilty party for the restoration of the environment and other important issues can be taken into account, the assessment of which can initially be given in the rulings of the arbitration court, and only later be the subject of judicial review within the framework of criminal proceedings, when the criminal-legal assessment of the deed is given.

The fact is that Russian legislation does not speak of the environmental restoration as the goal of compensating for environmental damage, however, by establishing in Art. 77 of the federal law dated 10 January 2002, the obligation to compensate for damage in full, the legislator already seems to assume that it is mandatory to compensate for harm in monetary terns. The institution of compensation for harm caused by an environmental crime has traditionally ranked high among all the legal provision governing homogeneous groups of the environmental relations. At the same time, the majority of researchers tend to hold the opinion that compensation for environmental damage is an intersectoral legal institution [11].

Some insight was provided after the adoption of the resolution of the Plenum of the Supreme Court of the Russian Federation "Issues of the Application of Legislation on Compensation for Harm Caused to the Environment" on 30 November 2017. The resolution provided a definition, according to which compensation for harm caused to the environment is made in accordance with the Civil Code of the Russian Federation, the Land Code of the Russian Federation, the Forest Code of the Russian Federation etc. Property, disciplinary, administrative and criminal liability can be established for violation of environmental protection legislation. At the same time, failure to bring a person to administrative, criminal or disciplinary liability does not rule out imposing on him/her the obligation to compensate for environmental damage. Similarly, it does not provide a basis for releasing a person from administrative, criminal or disciplinary liability from the obligation to eliminate the violation and compensate for the harm caused by him/her [12].

As previously noted, the structure of the harm caused as a result of the commission of crimes is quite complex. In addition to the environmental damage itself, it may include physical harm to health, pecuniary damage and non-pecuniary damage [13]. Moreover, our analysis of criminal cases on the considered environmental crimes showed that only every third court ruling contains some information on compensation for the damage caused (compensated in full or in part, the amount of damage, recovery procedure if a crime is committed by a group of persons, etc.). On 13 February 2018, the Ilovlinsky District Court of the Volgograd Region issued a verdict in a criminal case against B., director of Mostovik Limited Liability Company, who was found guilty of committing a crime under Art. 246 of 
the Criminal Code of the Russian Federation (violation of environmental protection rules during the performance of work). At the hearing, it was established that $\mathrm{B}$. on the agricultural plot of land in the Krasnodon rural settlement, in violation of the legal provisions, had developed a sand pit. At the same time, a fertile soil layer was removed in an area of 2 hectares with a mining depth of 3-4 metres. In total, B. was able to export and sell over 10,400 tons of sand. In addition, in order to export the mined sand for sale, the merchant arranged for the passage of equipment through the adjacent area of the state forest fund. As a result, the forest litter was destroyed and forest plantations were damaged on an area of almost 500 square metres. Damage to natural resources from illegal activities exceeded 20 million roubles. Taking into account the circumstances of the crime, the identity of the defendant and the opinion of the state prosecution, the court sentenced B. to 1 year 6 months' imprisonment in a penal colony settlement. Later, the prosecutor's claim against Mostovik LLC was considered and satisfied to impose on the merchant the obligation to develop a project and reclaim the soil disturbed as a result of the quarrying operations. By the ruling of the Gorodishchensky District Court of the Volgograd Region, the prosecutor's statement of claim against Mostovik LLC regarding the recovery in favour of the Russian Federation of funds in the amount of 3 million roubles received from the sale of sand was satisfied. However, conspicuous is the fact that the amount of damage caused to natural resources exceeded 20 million roubles, and the statement of claim was filed by the prosecutor only in the amount of 3 million roubles [14].

\section{Conclusion}

In summarising the above, inference should be drawn that Russia has not yet developed uniform approaches to determining the amount of and procedure for compensation for damage caused as a result of committing environmental crimes; nor any dedicated environmental courts have been created, the judges of which should have more extensive experience in considering such disputes than their counterparts in arbitration courts and courts of general jurisdiction, since the availability of them will be a mandatory criterion for appointing them. In the absence of a corresponding civil claim, the court shall not have the right to take a decision on compensation for harm on its own initiative when passing a sentence. The compensation amount awarded by the court shall be proportionate to all the circumstances characterising the gravity of the crime committed and all the consequences of the crime for the victim.

\section{References}

1. The state of crime in Russia in January-December 2020, Collection Main Information and Analysis Centre of the Russian Ministry of Internal Affairs. Accessed on: March 10, 2021. [Online]. Available: https://мвд.pф/folder/101762/item/12167987/

2. Report on the Operations of Courts of General Jurisdiction on the Consideration of Criminal Cases at First Instance. Accessed on: March 12, 2021. [Online]. Available: http://www.cdep.ru/index.php?id=79\&item $=5671$

3. Decree of the President of the Russian Federation of 19 April 2017 No. 176

"Environmental Safety Strategy of the Russian Federation up to 2025", Accessed on:

March 12, 2021. [Online]. Available:

http://www.consultant.ru/document/cons_doc_LAW_215668/ 
4. A.V. Kodolova, A.M. Solntsev, Antinomies, 19(1),112-127 (2019), Accessed on: March 15, 2021. [Online]. Available:

https://cyberleninka.ru/article/n/privlechenie-k-otvetstvennosti-za-prichinenie-vreda-ok ruzhayuschey-srede-v-rossii-i-zarubezhnyh-stranah-puti-sovershenstvovaniya

5. News of the ecology of Russia. Environmental violations entered the green zone. The amount of penalties for harm to nature was less than 1 billion roubles. Accessed on: March 10, 2021. [Online]. Available:

https://cntd.ru/news/read/novosti-kologii-rossii-kologicheskie-narusheniya-voshli-v-zel enuu-zonu-summa-vzyskaniy-za-vred-prirode-sostavila-menee-1-mlrd-rub

6. V.S. Martyanov, Strategic Opportunities of Russia: Environmental Priorities of the Future Economy, in Innovative Russia: Collection of articles. works of laureates and diploma winners of the Russian Competition of Intellectual Projects "Derzhava-2009", 123 (Forum, Moscow, 2010)

7. Environmental Impunity: Number of Punishments for Environmental Offences Dropped to a Three-Year Minimum. Accessed on: February 28, 2021. [Online]. Available: https://finexpertiza.ru/press-service/researches/2020/ekobeznakazannost/

8. The Krasnoyarsk Territory Arbitration Court issued a judgement in the case of compensation for harm caused to the environment in the city of Norilsk. Accessed on: February 28, 2021. [Online]. Available: https://krasnoyarsk.arbitr.ru/node/21390https://pravo.ru/news/223776/?desc_news_26=

9. Norilsk Nickel pointed out inaccuracies in calculating the record fine for an accident; How much the damage assessment can decrease when taking into account the company's arguments. Accessed on: March 10, 2021. [Online]. Available: https://www.rbc.ru/business/06/08/2020/ 5f2a7ae39a79472d69c9fe66

10. The Budget Code will be amended to compensate from Norilsk Nickel. Accessed on: March 5, 2021. [Online]. Available: https://pravo.ru/news/223776/?desc_news_26=

11. N.V. Gulak, Newsletter of OGAU, 2(52) (2015). Accessed on: February 1, 2019. [Online]. Available:

https://cyberleninka.ru/article/n/ponyatie-i-pravovye-sposoby-vozmescheniya-vreda-pr ichinyonnogo-ekologicheskim-pravonarusheniem

12. Resolution of the Plenum of the Supreme Court Resolution of the Plenum of the Supreme Court of the Russian Federation of 30 November 2017 No. 49 "Issues of the Application of Legislation on Compensation for Harm caused to the Environment". Accessed on: March 6, 2021. [Online]. Available: https://www.garant.ru/products/ipo/prime/doc/71723290//

13. N.V. Vukolova, Lawyer, 7, 49-54 (2015), Accessed on: February 1, 2019. [Online]. Available: http://отрасли-права.pф/article/11829

14. In the Volgograd region, the court issued a verdict in a criminal case on violation of the rules of environmental protection during quarrying operations. Accessed on: February 1, 2019. [Online]. Available: http://genprokufo.ru/about/info/messages/2753/?type=pda 